\title{
Differences in Electricity Generation from Renewable Sources from Similar Environmental Conditions: The Cases of Spain and Cuba
}

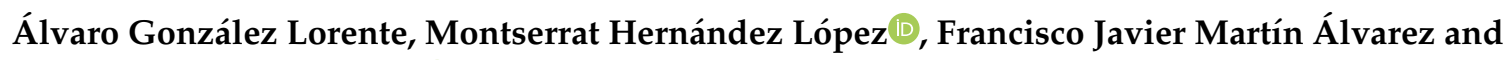 \\ Javier Mendoza Jiménez *(1) \\ Facultad de Economía, Empresa y Turismo, Universidad de La Laguna, 38250 San Cristóbal de La Laguna, Spain; \\ allorent@ull.edu.es (Á.G.L.); mhdezl@ull.edu.es (M.H.L.); fjmartin@ull.edu.es (F.J.M.Á.) \\ * Correspondence: jmendozj@ull.edu.es
}

Received: 19 May 2020; Accepted: 23 June 2020; Published: 25 June 2020

\begin{abstract}
In order to achieve the objectives set by the Sustainable Development Goals and the Paris agreement, the legislative framework that is developed at the national and regional level must be appropriate. Research has focused on the importance of environmental policies to stimulate renewable energy demand and has also highlighted the existence of legal regimes more inclined to preserve the current model of dependence on fossil fuels. The main aim of this paper is to observe the impact of different regulation framework in the use of renewable energies in electricity generation. The choice of Spain and Cuba was based on several reasons: first, they present different models of legal regulations for renewable energies, with more centralized power in the case of Cuba and more influence of supranational institutions in the case of Spain; second, they have similarities regarding their productive model (highly dependent on hydrocarbons as sources of electricity generation) and the high potential for electricity generation with renewable energies thanks to their rich natural endowment that could favor energy generation from sources like the sun, wind and water; finally, both countries face a global situation where they could take advantage of this cost-cutting moment, and therefore, of electricity tariffs, to propose a sustainable model of electricity generation based exclusively on renewable energies. The conclusions show that Spain can become a role model to improve the Cuban system, given that the European and Spanish "green" positions can be very useful in developing Cuba's future energy model based on renewables. The existing ties between the Caribbean country, Spain and the European Union (EU) should be the basis to support a model for which Cuba has an outstanding endowment of natural resources and where the similarities with Spain can generate synergies based on the European experience.
\end{abstract}

Keywords: legislative framework; renewable energies; electricity generation; Cuba; Spain

\section{Introduction}

The 2015 Paris Agreement established that the global increase in the temperature of the planet must be less than two degrees. In December 2018, the Katowice rulebook was developed to comply with the Agreement's goals. In addition, the 2030 Agenda for Sustainable Development of the United Nations' seventh objective is to achieve affordable and non-polluting energy. All these highlight the momentum of a sustainable global agenda, which entails transforming our economic model into a more global, concerted and multilateral one that lays the foundations for total decarbonization.

The evolution in the energy market seems to support this change. In 2017, there was such a decrease in solar power prices that it became the cheapest source of energy in much of the world. In 2018, the cost of production of renewables for the first time was lower than that of non-renewables; 
and already in the first months of 2019, solar and wind power have become the cheapest energy sources in almost 60 countries. The main reason for this evolution and this cost reduction, according to a report by the International Agency for Renewable Energies-IRENA [1]—is the reduction in the cost of the installation of solar panels and wind turbines, as well as the reduction in production costs due to improved storage technology and better network implementation.

In fact, the environmental proposals of many countries are currently focused on the generation of electricity from renewable sources. Renewable generation capacity expanded by $7.4 \%$ in 2019 and represented $72 \%$ of the new additions to the world's power generation [2]. The study of [3] summarizes the main effects of renewable energies in climate change mitigation and enounces some of the main challenges to be faced. In [4], the focus was on new ways of producing electrical energy from oceanic waves while [5] used the results of the Stanford Energy Modeling Forum Study 27 to compare 18 energy-economy and integrated assessment models (none of them coming from Spain or Cuba) and concluded that the alternatives in the sector harm the development of low-carbon alternatives.

On the future of renewable energies, [6] indicated that a cost reduction is expected thus helping to increase the mitigation impact on climate change of these. Nevertheless, the path to achieve a more sustainable model of production is not exempt of uncertainty and errors [7] and the role of local actions is key to increase the presence of alternative energy sources [8]. According to [9], the five elements of change that drive the future of renewable energy are: regulatory reform and support for public policies, the commitment of companies, financing innovation, energy storage and network integration.

There are two main objectives that are being pursued by replacing electricity generation with non-renewable sources with that based on renewable sources. The first is to help reduce the emissions of greenhouse gases. Greenhouse gases are produced in the combustion of fossils. In this combustion, in addition to the solar energy stored in the chemical bonds of the hydrocarbon chains, the carbon combined with the oxygen in the atmosphere produces and releases carbon dioxide $\left(\mathrm{CO}_{2}\right)$. The emission into the atmosphere of greenhouse gases from fossil fuels in the EU increased by $1.8 \%$ in 2017 compared to its level of 2016, with Spain being the fourth EU country where greenhouse gases (GHGs) have grown. The reasons for this increase can be found in meteorological and climatic conditions, environmental and energy policies, economic growth itself and the possible demographic movements in each country (as an example, and according to the data from the National Bureau of Statistics and Information of Cuba (ONEI), in 2013, about 262 grams of fuel were needed on the island to generate 1 kilowatt hour (KWh), emitting in the generation process 1127 grams of $\mathrm{CO}_{2}$ per $\mathrm{KWh}$. It is estimated that the emissions for 2030 will be $11.7 \%$ lower than in 2013, standing at 993 grams of $\mathrm{CO}_{2}$ per $\mathrm{KWh}$ ). The second is not to depend on sources that are depleted and subject to constant price increases: energy cannot be accumulated, so the price consumers pay, the electricity tariff, is the sum of the price per megawatt hour (hereinafter, MGh) of the last offer necessary to meet the demand (these megawatts are almost always produced by gas or coal, with high prices), plus the additional cost due to market restrictions or the minimum supply needs of the population, and, finally, taxes. This implies that the greater the dependence on a non-renewable source for electricity generation, the greater the impact of external fluctuations. Moreover, the price of non-renewable sources should include the damage caused to the environment. However, this damage is not often included because of the difficulty in quantifying it [10]. If external costs due to the damage to health and environment were taken into account, the costs of producing electricity from oil or coal and the cost of electricity and production from gas would increase.

A key question to be answered is how can we ensure that the old model of electricity generation from non-renewable sources is definitely abandoned, and that one that is entirely based on alternative renewable sources is adopted? Law seems to be one of the strongest pillars to that change of model. The article 191 of the Treaty of Functioning of the EU establishes the "polluter pays" principle, which appeared for the first time in the First Program of Environmental Action of the Community (Chapter 1) and was then incorporated into the Constitutive Treaty of the European Union in its article $130 \mathrm{R}$. The application of this principle to favor those that do not produce emissions, or the enactment 
of laws that prioritize electricity generation projects with renewable sources, are some of the legal ways to achieve this. However, they do not appear to be definitive.

Law seems to be one of the strongest pillars to that change of model. In the case of China, one of the main world polluters currently, a proposal has been made to go further than the polluter payment towards the stricter "causer responsibility principle" [11]. The debate over how to modify the economic regime is still ongoing [12], public procurement being among the most effective ways in which more sustainable practices can be implemented [13].

Starting from here, the paper is structured as follows: in the first section, a short summary of the legal framework in renewable energies in both countries is made as well as the revision of the financing mechanisms that each one of these countries has to face the increase in costs that it implies, at least in the short term, the substitution of non-renewable sources by other renewable ones. In second section, this paper reviews the present and future of electricity generation from renewable sources in both countries. The third section is about the future of renewable energies in Spain and Cuba and the relationship between Cuba, the European Union and Spain in the field of renewable energies. The lines for collaboration between the European Union and Cuba and, more specifically, between Spain and Cuba, concerning electricity generation is already being established and will be addressed at the end of the third section. This paper finishes with the discussion on the influence of legislation in electricity generation with renewable sources and the future directions of research.

\section{Legal Framework in Renewable Energies: Comparison between Cuba and Spain}

\subsection{General Legal Framework}

\subsubsection{Cuba}

The energy policy in Cuba is based on the saving and rational use of energy, the transformation of its electricity system, the promotion of renewable energies, the greater use of national oil capacity and international cooperation [14]. Already in 2013, the electricity-generating units that use hydroelectric energy, sugar cane biomass (from sugar cane), direct solar radiation and wind produced an amount of electricity equivalent to that generated in the country for 15.8 days. This also has a positive economic and environmental effect, as it does not require fossil combustion and thus prevents greenhouse gas emissions.

In 2014, Cuba stated the need to transform its energy supply in order to produce cleaner, more diverse and efficient energy. To do this, it created a Government Commission to develop a Policy for the Prospective Development of Renewable Sources and the Efficient Use of Energy, with the aim of accelerating the development of renewable energies, transforming the structure of energy sources, reducing dependence on imported fossil fuels, improving efficiency in energy generation and increasing environmental sustainability [15].

The Plan of the Policy for the Prospective Development of Renewable Sources and the Efficient Use of Energy aims to achieve that renewable sources in energy production reaches $24 \%$ in 2030 with the following distribution: biomass (would represent $14 \%$ ), wind power $(6 \%)$, solar power $(3 \%)$ and hydroelectric power (1\%). Cuban energy supply at that time had a high dependence on imported fuels, a high average cost of delivered energy, high environmental pollution and a low use of renewable energy sources. The policy proposes that, by $2030,24 \%$ of electrical energy will be produced from renewable sources, when it was currently around $4 \%$, and the total KWh produced will also increase, reaching $7316 \mathrm{GWh} /$ year, in addition to reducing $\mathrm{CO}_{2}$ emissions by 6 million tons [16].

To do this, they intend to build 25 bioelectric plants and 14 wind farms, in addition to small hydroelectric plants, biogas plants and solar farms, with the help of foreign investment. Specifically, the aim is to raise USD $\$ 4$ billion in external funds through the projects presented in the latest Portfolio of Opportunities for Foreign Investment published by the government last year.

For biomass, there are already three projects in the execution phase and ten in the negotiation phase. One of them, started in April last year, involves the construction of the first bioelectric plant 
with the participation of foreign capital from companies in China and the United Kingdom. However, there are still 14 available projects in the portfolio of opportunities. In the field of wind energy, there are currently two wind farms in execution, one in credit management and the remaining ten in negotiation with foreign investors.

Regarding solar energy, 40 of the 201 planned solar photovoltaic parks are already in operation and it is expected that by 2018, 58 more will be launched. The rest are still in the negotiation phase. Lastly, hydropower is pending the obtaining of a credit for the generation of $41 \mathrm{MW}$ of power, of the planned total of $56 \mathrm{MW}$.

Already in 2019, the Cuban Energy Policy Support Program was signed in Havana, developed as a cooperation strategy between the EU and Cuba, and whose purpose is to support the country's government in the efficient and sustainable management of its resources.

To support the achievement of those objectives, in 2019 entered into force the Law-Decree 345 regarding the development of renewable sources and the efficient use of energy. The document is divided into four chapters and among its aims (article 1) is established, among others, increasing the participation of renewable sources in the generation of electricity; the stimulus of the investment of the use of such sources and the establishment of a working plan in the public sector.

One of the peculiarities of the Cuban case, apart from the preeminence of the public sector in the electricity sector, is the inclusion of the sugar cane biomass as one of the renewable resources for electricity, which normally is included inside the general biomass.

The investments are another important piece of regulation in this Decree, since Cuba has been traditionally restrictive with them. In this case, an exceptional opening can be observed for foreign investments that are entitled to different fiscal and economic benefits. Similar conditions apply to those nationals importing the necessary equipment.

The law does not set concrete objectives to be reached in a certain period of time, but the article 15 does regulate the possibility of self-production by independent producers (independent from the public system) whose energy has to be bought by Unión Eléctrica-the national electric company. With this law, Cuba allows the production and selling of renewable energy by small producers, which is a big step towards a more decentralized and efficient system.

\subsubsection{Spain}

The normative framework in Spain regarding the production of electricity is composed of three documents. First, the Royal Decree Law 9/2013 adopting urgent measures to guarantee the financial stability of the electrical system by modifying the system for the cost calculation of the generation of electricity. Secondly, the Law 24/2013, of 26 December, of the Electrical System, which substitutes the Law 54/1997 and transposes the mandate of the Directive 2009/72/EC. This law does not set a specific objective for the generation from renewable sources and does not significantly regulate their production. This task belongs to the third piece of legislation, the Royal Decree 413/2014, of 6 June, that regulates the production of electricity from renewable energies, cogeneration and waste.

In there, an important part of the legal text is devoted to the concept of reasonable profitability which, in the case of generation from renewable sources, has been subject to long and complex litigations between the State and the investors.

The Royal Decree-Law 17/2019 of 22 November was approved to adopt urgent measures (again) for the retribution of the electrical system. The legislation describes the current context of energy production where many thermal power plants are close to stopping their activities. Therefore, it is imperative to promote renewable sources to close the gap those powerplants have surely left.

This law also includes measures for a fair transition from coal to renewable sources. The foundations of the future Spanish energy model of the Strategic Energy and Climate Framework presented in February 2019 are the Climate Change and Energy Transition Law, the National Integrated Energy and Climate Plan (PNIEC) 2021-2030, and the Strategy for a Fair Transition [17]. 
The Preliminary Draft of the Law on Climate Change and Energy Transition indicates that it is intended to ensure compliance with the objectives of the Paris Agreement, to facilitate the full decarbonization of the Spanish economy, so that a rational and solidary use of our resources be guaranteed, and that the implementation of a sustainable development model generates decent employment. For its part, the National Integrated Energy and Climate Plan (PNIEV) 2021-2030, has among its aims to reach, in 2030, $42 \%$ renewable energy in the overall energy use of the country, reaching $74 \%$ renewable energies in electricity generation, and the energy dependence on the exterior diminishes by 15 percentage points, going from the current $74 \%$ to $59 \%$. Finally, the Fair Transition Strategy will establish a comprehensive territorial action plan for those regions where the energy and ecological transition may pose difficulties for economic activity [18].

The Spanish legal framework for renewable energy production has been the object of multiple discussions, both praising and (mostly) criticizing it. At the European level, [19] used the case of Spain when analyzing the harmonization attempts at the European level in renewable electricity production and highlighted the importance of a voluntary cooperation mechanism even over more legally binding strategies.

The good effects of the raise of the renewable energies are related to the creation of cooperatives in the field [20] and the increase in competition in the market [21]. On the other side, the "rollercoaster" of regulatory changes [22] has led to a certain paralysis for the sector in Spain [23].

On the future of the Spanish energy system, [24] mentioned the overcapacity for the penetration of the renewable energies. In the same vein, [25] pointed at the electricity excess as one of the constants of the system, with an estimate annual surplus for the year 2050 ranging between 1.4 and 13.5 TWh. Girard et. al [26] looked at different scenarios for the year 2030 and concluded that Spain "must reduce its energy consumption by $23 \%$ and achieve $100 \%$ renewable energy" to guarantee the sustainability of its production system.

\subsection{Financing Mechanisms}

One of the key factors of debate for the promotion of renewable energies is the effectiveness of instruments that penalize GHG emissions produced by non-renewable sources [27]. According to Abolhosseini, and Heshmati [28], there are three main instruments for this: production rates, tax incentives and green certificates. The comparison between the two cases of analysis of this study shows that Cuba and Spain are in totally opposite places in terms of the development and implementation of these types of mechanisms, which is reflected in the existing legislation analyzed below.

In the case of Cuba, which is still at an initial stage, a support mechanism is needed that accelerates the use of renewable sources and finances the costs of the electricity production with renewable sources. The aforementioned regulation of 2019 was complemented with the Instruction 6/2019 of the Central Bank of Cuba, regulating the concession of credits to natural persons (not private businesses) for the acquisition of equipment using renewable sources.

Although the type of equipment to be financed is limited (solar water boilers and photovoltaic solar systems), the existence of this possibility for financing this specific material is another advance towards a more developed system.

In the case of Spain, the mechanisms for financing renewable energies have focused mainly on tax incentives that have been introduced and eliminated in the last 20 years. Royal Decree 2818/1998 of 23 December, on the production of electricity by facilities supplied by renewable resources or waste and cogeneration energy sources establishes in its Article 1.c the introduction of a premium "for those installations greater than $50 \mathrm{MW}$, that use non-consumable and non-hydraulic renewable energy, biomass, biofuels or agricultural, livestock or service waste as primary energy sources" [29].

These premiums were a boost to the production of energy from renewable sources. However, they were cancelled during the economic crisis by Royal Decree-Law 1/2012, 27 January, which suspended the procedures for the pre-allocation payments and eliminated the economic incentives for new installations producing electricity from cogeneration, renewable energy sources 
and waste [30]. This Royal Decree/Law was a step backwards in policies promoting the production of renewable energies, which met with another notable obstacle with the approval of the Royal Decree 900/2015, of 9 October, which regulates the administrative conditions, technical and economic modalities of electricity supply and production for self-consumption [31]. This legislation introduced, what became commonly known as the "sun tax", which penalized self-supply when remaining connected to the electricity grid.

However, the Royal Decree/Law 244/2019, 5 April, reverted the situation and regulates three kinds of self-consumption: with no surplus, with surplus subject to compensation and with surplus without compensation. Together, with some measures aiming to simplifying the bureaucracy and allowing a bigger development of this sector, it is expected that the generation of energy from this source will experience a positive evolution in the coming years. According to the data of Red Eléctrica Española, the weight of the solar energy has increased from $7.7 \%$ of the total in 2018 to $9.4 \%$ in 2019.

The influence of European legislation on the renewable energy policies of Spain must be analyzed, since the recent Renewable Directive that will take effect from 2020 to 2030 states that the sun tax is illegal and self-consumption should be supported as a way to promote renewable energy. Indeed, the Royal Decree 244/2019 of 5 April, which regulates the administrative, technical and economic conditions of electricity self-consumption, is a positive change in the regulations and incentives of self-consumption, decreasing obstacles to it and definitely repealing the "sun tax" in the national framework [32].

In relation to this general framework of the European Union and renewable energies, there are four ways of financing that try to compensate the efforts made to curb climate change and promote the generation of energy from clean sources:

1. Revenue from the auction of the emissions;

2. NER 300. Projects for financing innovation in renewable energy and $\mathrm{CO}_{2}$ capture and geological storage;

3. Integration of climate policies in the EU budget: Structural Funds, Common Agricultural Policy, Horizon 2020 Initiative, European Fund for Strategic Investments and Climate Action Sub-program of the Life Program;

4. Emission trading system (ETS): The legal framework of ETS determines that the companies and other participants negotiate directly and the rights are only stored in electronic records created by the Member States. Each country distributes the rights in the same way: $43 \%$ are granted free of charge to certain companies and the remaining $57 \%$ are auctioned in a market, for example to which coal-fired power stations go to buy rights to meet their requirements. The bases are in the Directive 2003/87/EC of the European Parliament and of the Council of 13 October 2003, establishing a scheme for greenhouse gas emission allowance trading within the Community, and amending Council Directive 96/61/EC.

\section{Electricity Generation from Renewable Sources in Cuba and Spain: Present and Future}

\subsection{Cuba}

The electricity generation in Cuba in 2016, the last year for which data is available, shows that about $4 \%$ of the total energy produced is obtained from renewable sources (see Figure 1, with data from the International Energy Agency (IEA) [33]). Moreover, and according to the quantitative information provided by the International Energy Agency (IEA), this percentage has varied from around $10 \%$ in the early 1990s to levels close to $4 \%$ from the year 2008 onwards. It is thus noticeable, that in Cuba, the use of renewable sources, instead of increasing, has decreased, caused, above all, by the reduction in biofuel use. 


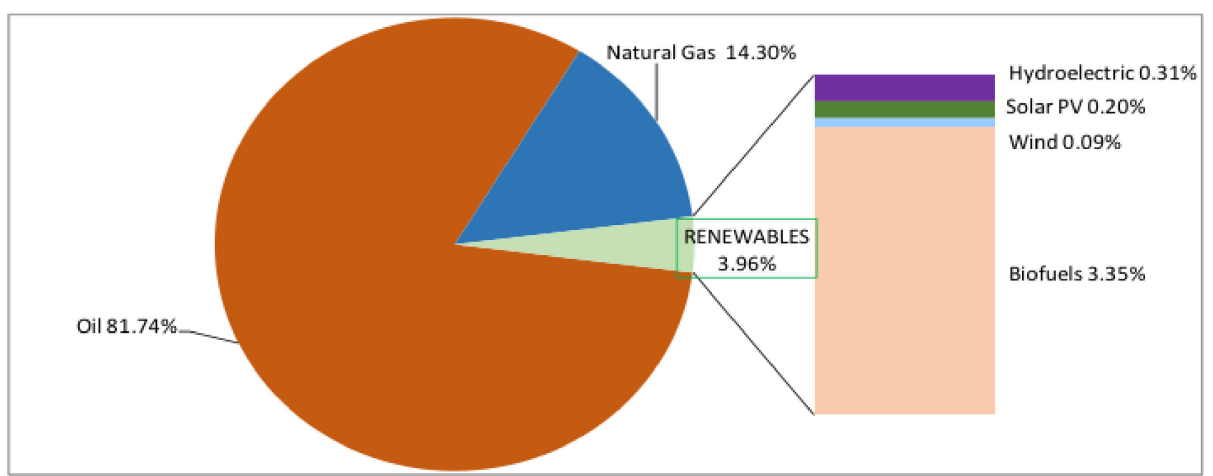

Figure 1. Sources of electricity generation in Cuba, year 2016.

As for wind power, in 2015, there were about 7000 windmills that gave an estimated saving of 30,000 tons of diesel per year [34]. However, the Cuban Electric Union plans to install an annual production of 100 gigawatts in 13 wind farms on the island, increasing by nine the number of current farms, especially to the north of the Eastern Center of the Island, which would represent $5.5 \%$ of the total energy forecast for 2030, increasing from $0.09 \%$ in 2016 (see Figure 1). In 1999, the first wind farm in Cuba was built. According to meteorological studies, Cuba is favored by the Atlantic anticyclone, whose winds overlap with the breezes of the North Coast, providing great force (considering that "the minimum average wind speed for which it is feasible to obtain electricity from wind power fluctuates between $16 \mathrm{~km} / \mathrm{h}$ and $23 \mathrm{~km} / \mathrm{h}^{\prime \prime}$ [20] (p.19).).

This is complemented by certain local currents, far from the coast, but favored by reservoirs, valleys and mountains. In 2005, work began on the assembly of the Los Canarreos wind farm on Isla de la Juventud, which has six wind turbines and will record a total power of $1.65 \mathrm{MWh}$. In the municipalities of Gibara in Holguín, and in the north of the province of Las Tunas, there are the other wind farms with higher production [34].

Processing the data from six meteorological stations and selecting the one with the highest power, [35] concluded that the production costs of the wind power per KWh were between 4.6 and 6.0 cents. The negative characteristic of this renewable source is, in addition to its high investment costs, the fact that it cannot cover all the demand due to the intermittency of the wind and the sudden breaking of turbine blades caused by any overcurrent that is detected.

As far as photovoltaic solar power is concerned, the Cuban solar map shows practically uniform radiation throughout the country, and although its investment would take longer to recover than those of other renewable energies, it is estimated that, in 2030, the sun could generate $3.5 \%$ of the country's total energy, while in 2016 it only accounted for $0.2 \%$ (see Figure 1). Keep in mind that in Cuba, solar radiation reaches about 5 KWh per square meter per day (about $1825 \mathrm{KWh}$ per square meter per year), distributed throughout the national territory, so it is rated as good even compared to some European regions where this source has a high level of application. Solar radiation varies so little in Cuba with estimates of less than $8 \%$ variation in more than $97 \%$ in all areas of the island [36].

In the country, 180 hydroelectric plants are operating, which in 2030 will account for $1 \%$ of the total energy generated, thus registering a sharp increase compared to $0.31 \%$ that it represented in 2016 (see Figure 1). It is estimated that, in recent years, around 35,000 Cubans have benefited from this type of electricity, generated mostly in La Hanabanilla, in the province of Villa Clara, where the largest hydroelectric plant is, which produces about $43 \mathrm{MWh}$. In 2015, the hydroelectric power generation installed in Cuba was about $64 \mathrm{MWh}$ with an estimated potential of $800 \mathrm{MWh}$ [34].

Finally, regarding bioenergy, its three components must be analyzed. These are biomass, organic matter of vegetable or animal origin from urban solid waste, animal excreta, rice husk vegetable oils and sawmill residues, or energy crops. These primary and secondary biofuels derived from biomass can be used to produce thermal energy. Sugar cane biomass "is the most widespread renewable energy whose use is in Cuba. ( ... ) The country's biogas production provides electricity generation of 
$85 \mathrm{MWh}$ and produces around $700 \mathrm{GWh}$ per year" ([34], p. 21). The sugar industry in Cuba is the one that contributes most to the change in the national energy matrix, because sugar, when burned, does not increase the presence of $\mathrm{CO}_{2}$ in the atmosphere. By 2030, it is intended to put into operation 25 bioelectric plants that generate high levels of surplus electricity and represent $20 \%$ of the overall demand for electricity generation. However, this is far from $3.35 \%$ of the country's electricity generation in 2016 (see Figure 1).

If it is advisable in all countries to replace energy production from non-renewable sources with renewables sources, in Cuba, it is much more pressing. The trend shown in Figure 2 (with data from IEA) indicates a lack of result on effort to change the productive model. The percentage of renewable energies has gone from 3.2\% to 3.8\% in the period from 2005 to 2017 (and the situation was most probably even worse in earlier years), which indicates that policies for fostering alternative energy sources in Cuba have still a really low impact in reality.

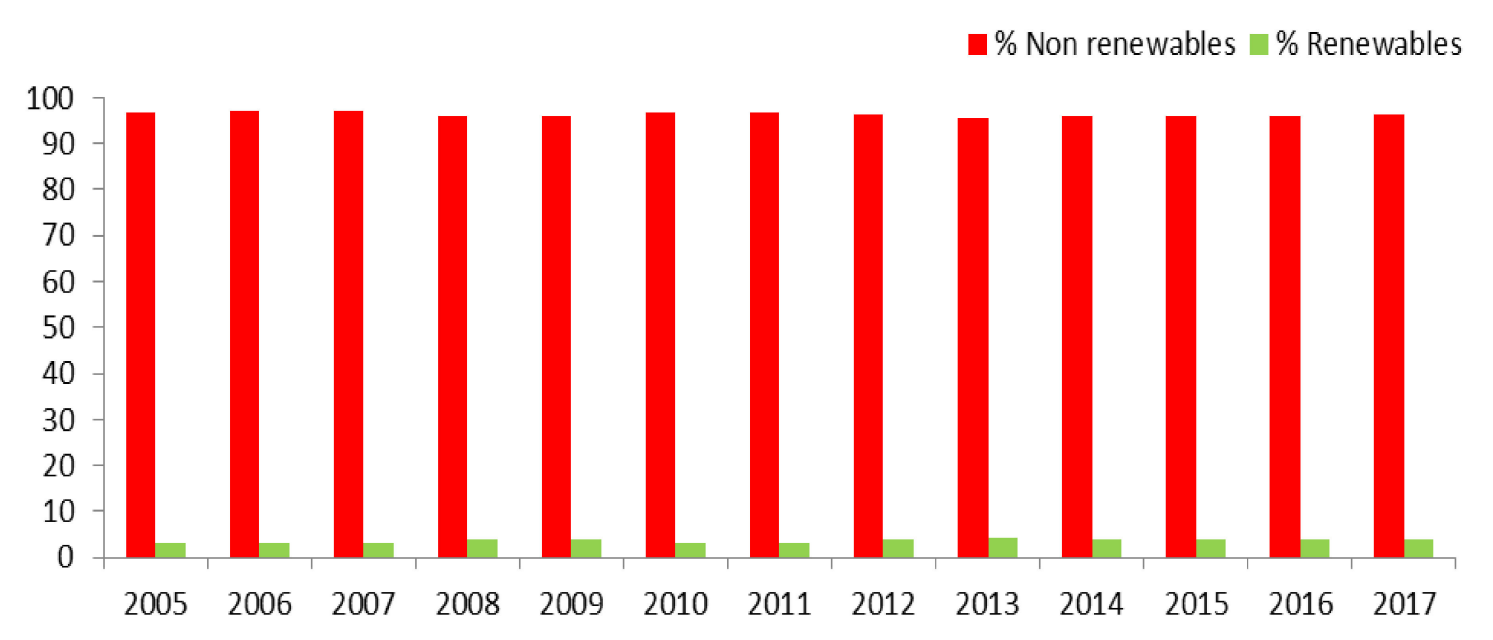

Figure 2. Electricity generation in Cuba by renewable sources type from 2005 to 2017.

The above is aggravated by the fact that, although in the Special Period that Cuba suffered after the fall of the Berlin Wall (1989) was overcome with the economic measures from the Government and Venezuelan aid, the new economic situation that Cuba seems to face 30 years later does not have, in principle, the same type of solution, since there seems to be no country that can take the place of Venezuela. When Venezuela stops sending oil to Cuba, and Cuba does not have liquidity to buy oil from other producing countries, it would face a new economic crisis.

Figure 3 (with data from IEA) shows the comparison of Cuba with other countries of the South American and Caribbean region in terms of electricity generation. As it can be seen, Cuba is the second country, after the Dominican Republic, with the least percentage of production from renewable sources. In the region, there are leading cases like Costa Rica, Uruguay and Paraguay where almost $100 \%$ of the electricity generation comes from renewable sources, but also countries in a similar situation to Cuba like Mexico and Dominican Republic, although these latter countries generate more than $10 \%$ of their electricity from renewable sources. Cuba is in a good position to learn from its neighbors and improve the current situation. 


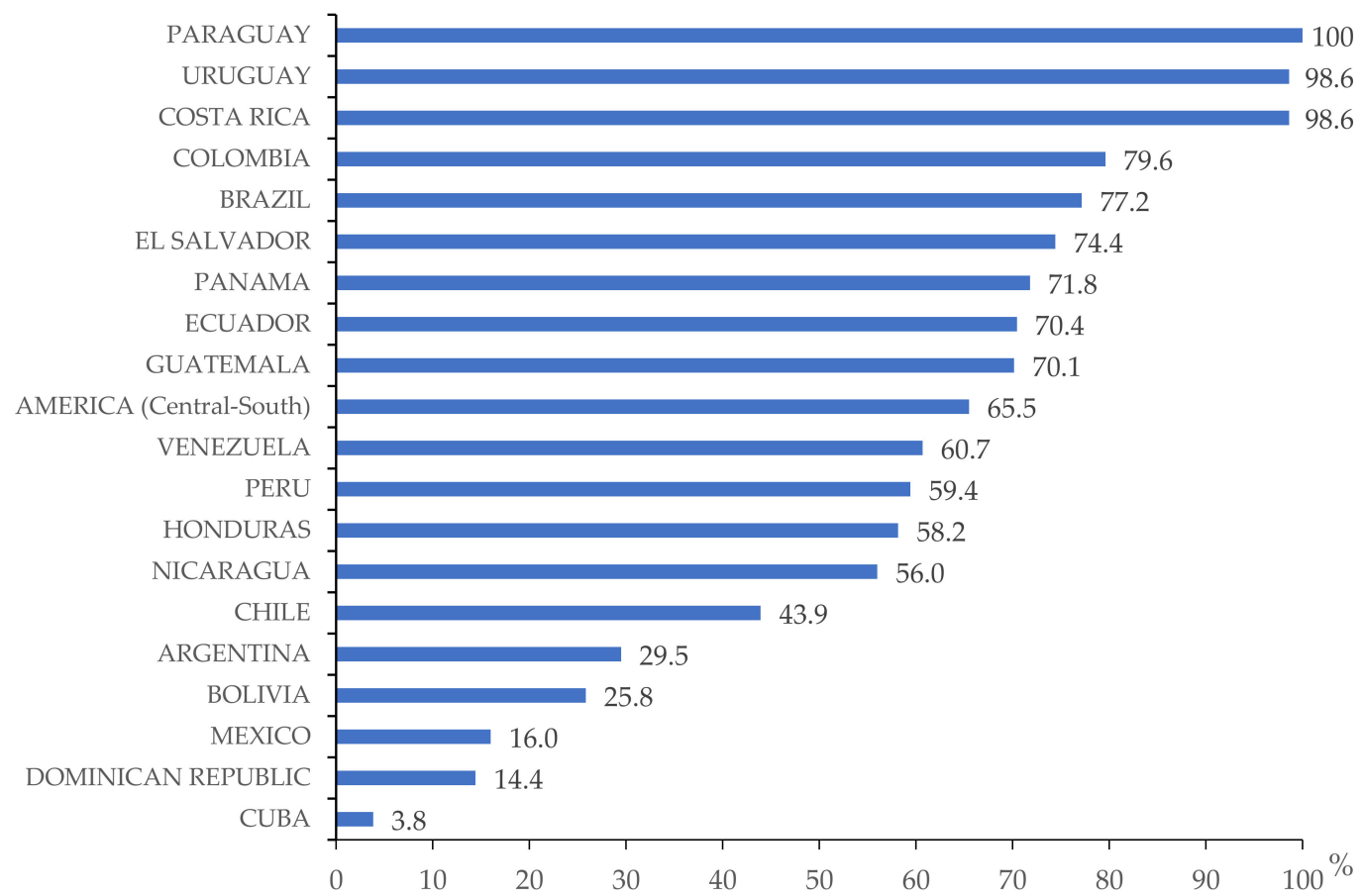

Figure 3. Electricity generation the South American and Caribbean Region by sources type (\%), year 2017.

\subsection{Spain}

The real situation of the energy sector in Spain in recent years does not differ substantially from that of other European countries, but it is true that it presents certain peculiarities such as its high external energy dependence; slightly mitigated by the diversification of sources and suppliers; the poor interconnection with Central and Northern Europe-in electricity, but also in gas-and a decrease in energy demand [37].

Electricity generation in Spain for 2016 shows that about 40\% was obtained from renewable sources (see Figure 4, with data from IEA). According to the quantitative information provided by the International Energy Agency, this percentage has varied from 17.7\% of the total in 1990 to levels close to $40 \%$ as of 2013 .

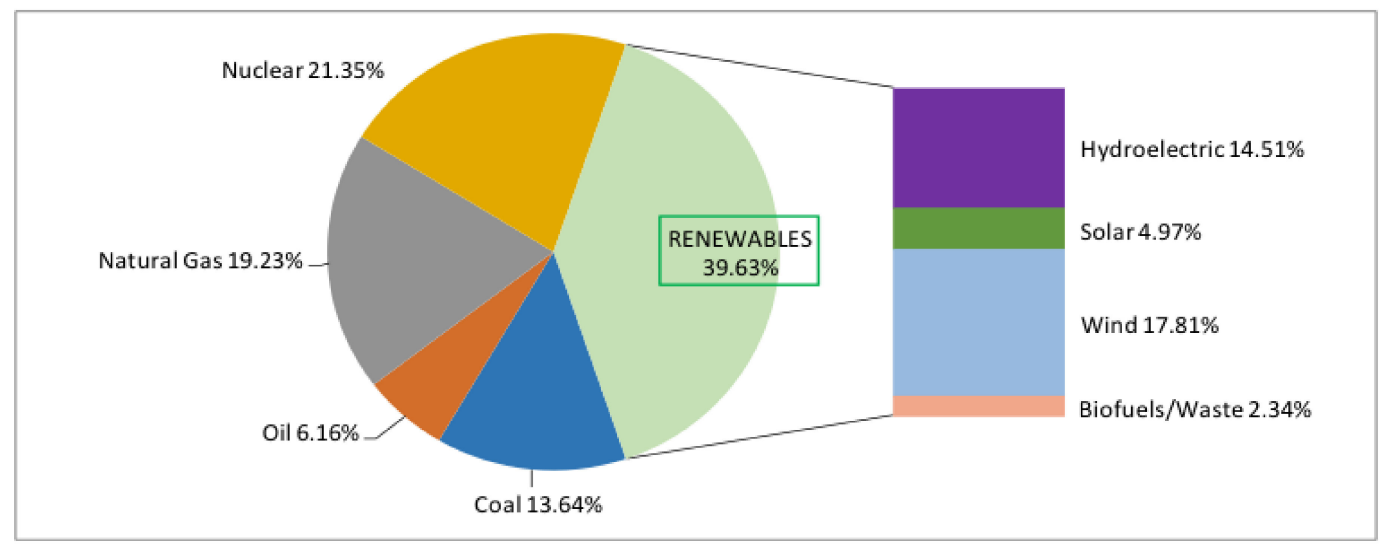

Figure 4. Sources of electricity generation in Spain, year 2016 (although there are updated data for 2019 in Spain, to facilitate the comparison with Cuba, the data for 2016 was used. The updated data can be found on the Spanish website of Red: https://www.ree.es/es/estadisticas-del-sistema-electrico-espanol/ series-estadisticas/series-estadisticas-nacionales (accessed on 3 April 2020).). 
Within renewable energies, the two sources that have contributed the most to this positive change have been wind power (wind) and geodetic jumps of water (hydroelectric). This places them in third and fourth positions in terms of total production, respectively, considering all the possible renewable and non-renewable energy sources, behind those from nuclear energy and gas.

As can be seen in Figure 4, in 2016, wind power generation in Spain accounted for approximately $18 \%$ of the total electricity produced in the country. This type of energy takes advantage of the kinetic energy of air currents to move giant wind turbines capable of converting them into electrical energy.

In Spain, generating wind power costs just USD 76 per MGh (data extracted from the information published, available online at: http://www.energiaestrategica.com/en-espana-generar-energia-eolicacuesta-apenas-76-dolares-el-mwh/ (accessed on 2 October 2019).), so in 2020, it is the cheapest way to generate electricity after hydroelectric power and ahead of fossil fuels. In addition, this renewable energy source prevents annual emissions of 28 million tons of CO2. This makes it one of the renewable energy sources with the most momentum in recent decades, with good short-term benefits and the reason why Spain is a pioneer in the technology for this energy.

Spain is the fifth country in the world for installed wind power, just behind China, the United States, Germany and India, with 1123 wind farms in 807 municipalities. These farms generate about $23,484 \mathrm{GW}$ of accumulated power [38]. This is despite the high cost of the initial investment and construction. There are other obstacles like connection to the network, the slowness to grant licenses, the ignorance of its environmental impacts and the difficulty to predict the amount of electricity that will be generated in the short term. All of these factors highlight that this is not the easiest source of renewable energy.

The contribution of hydroelectric power represents $14.51 \%$ of the total energy produced in 2016, but in recent years it has gradually decreased due to an increase in other types of energy. Hydraulic power is obtained from the movement of water in rivers and waterfalls. Hydroelectric power plants are built in strategic locations that can take advantage of the energy released by such movement to operate a generator, from which the electric power will be obtained.

The advantage of this system is that it produces clean, domestic energy. The disadvantage is that a certain infrastructure is required to hold large volumes of water. The hydroelectric plant with the highest current production in Spain is that of Aldeadávila, located in Salamanca, on the Duero River, with an average annual production of $2400 \mathrm{GWh}$.

One of the pending issues for Spain in the field of renewable energies is directly connected with solar power, or with the lack of it. Spain is one of the countries in Europe, and in the world, with the most hours of sunshine throughout the year. To take advantage of this solar power, Spain just needs to install collectors for the sun's radiation through, for example, the use of solar panels capable of transforming this energy into thermal energy or electrical energy. The aim, in the near future, is to install new photovoltaic power plants and solar energy use points, but there is still a lot to be done to reach satisfactory levels of energy production using solar radiation. Despite these positive characteristics, it is striking that in 2016, only $4.97 \%$ of the country's electricity generation was generated by solar power.

The weight of the energy from renewable sources in the Spanish system has duplicated from 2005 $(16.4 \%)$ to 2017 (33.2\%). However, as Figure 5 shows with data from the IEA, the last three years have seen a negative slope from the peak of $41.6 \%$ reached in 2014 , that recovered in 2016, but went down again in 2017.

The forecast for the year 2030 is that the cost of generating photovoltaic solar power will tend to fall below the average price of wholesale electricity throughout Europe. This means that prices will be between 20 or 25 euros per MWh in countries like Spain, where its generation is cheaper, and 50 euros the MWh, which is the cost of generating photovoltaic solar energy in London [39]. Despite the limited installation of new power (22 MWh in 2014, 49 MWh in 2015 and 55 MWh in 2016), the contribution of this sector to the reduction of greenhouse gas emissions is promising. It prevented 3047 million tons of $\mathrm{CO}_{2}$ emissions, and the import of 16.5 Terawatt hours of natural gas, which meant an economic saving of 355.9 million euros [11]. 


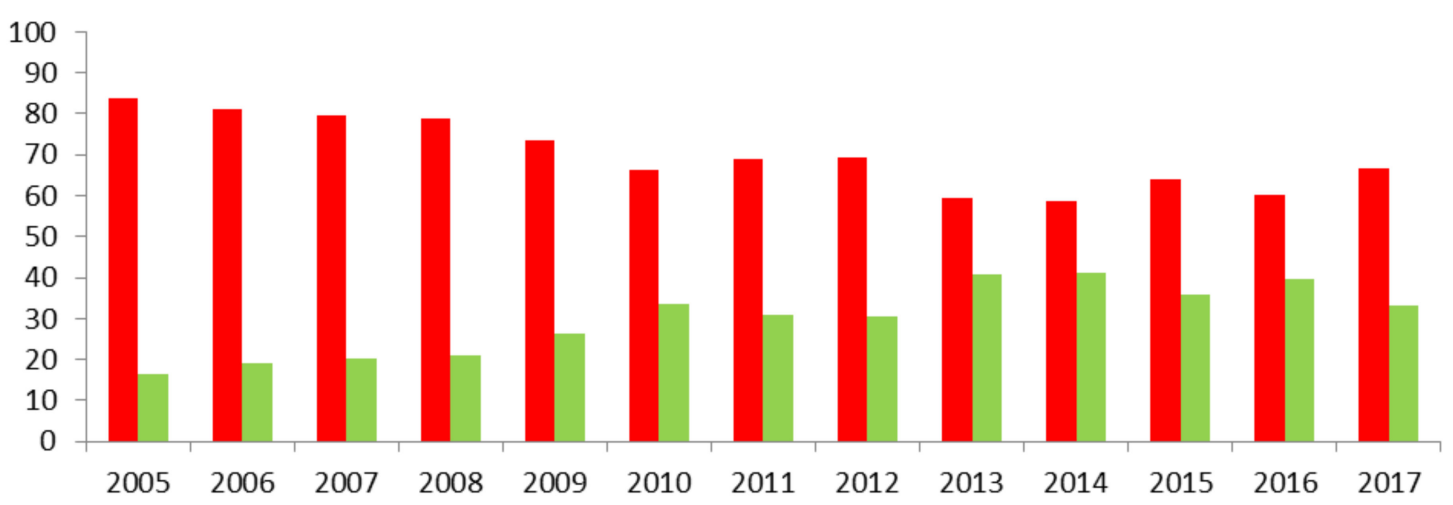

Figure 5. Electricity generation in Spain by renewable sources from 2005 to 2017.

In 2030, according to the EU Commission's report to the European Parliament and Council [40], $27 \%$ of the overall gross energy consumption of the European Union must come from renewable energies. This seemingly utopian goal is not so impossible if one takes into account that some European areas are already obtaining their electricity generation exclusively from renewable energies over a consecutive number of days. This is the case of the Canary Island (Spain) of El Hierro in which its Gorona del Viento Hydroelectric Power Plant [41] has managed to supply the entire electricity demand of the Island for 18 consecutive days using only renewable energy (data extracted from the information published, available online at: http://www.goronadelviento.es/el-hierro-18-dias-consecutivos-al-100con-renovables/ (accessed on 8 September 2019). The generation system takes advantage of the surplus wind to pump water between a lower and upper reservoir; the water that is accumulated in this latter deposit is responsible for producing electricity from the hydraulic jump when there is not enough wind (data extracted from the information published, available online at: http://www.goronadelviento.es/ (accessed on 17 December 2019).).

Figure 6 (with data from the IEA) shows the comparison of Spain with other countries of the European Region in terms of electricity generation. As can be seen, in electricity generation with renewable sources, Spain is at the European average. In the region, there are leading cases like Albania, Iceland $(100 \%)$, and Norway where almost $100 \%$ of the electricity generation comes from renewable sources, but also countries in a similar situation to Spain like Germany, Italy, and the United Kingdom. Spain should further boost its electricity generation from renewable sources, taking into account the country's natural conditions. 


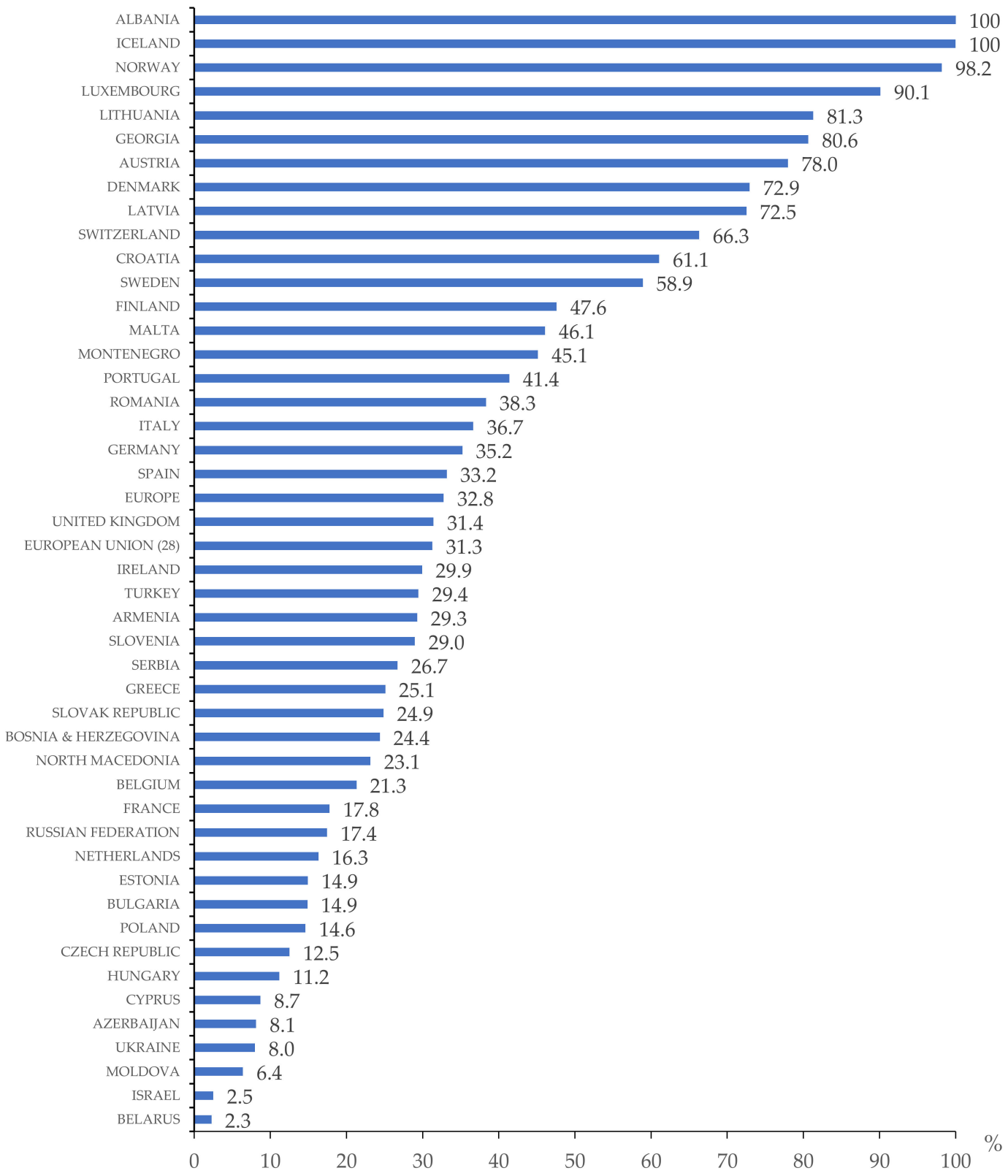

Figure 6. Electricity generation in the European Region by sources type, year 2017.

\section{The Future of Renewable Energies in Spain and Cuba and the Relationship among Cuba, the European Union and Spain in the Field of Renewable Energies}

The Paris Agreement established in its article 3 the "nationally determined contribution" (NDC in advance) as the vehicle for the communication of the signatory parties regarding the actions to be developed by them to achieve the objectives of the agreement. Nowadays, a vast majority of the countries (up to 186 according to the NDC registry) have submitted their documents.

Nor the EU NDC or the Cuban one make explicit reference to policies directly involving renewable energies. The EU NDC, sent in 2015 under the Latvian presidency, serves as an umbrella for all EU members and included (among other aspects) a reduction in GHGs of $40 \%$ by 2030 - compared with the 1990 level-that could extend to $80-90 \%$ by 2050 . The sectors covered by the EU NDC goes from energy to agriculture and waste, and the legislative changes it proposes address different aspects such as land use and forestry. There is a firm compromise to build "legislative proposals to implement 
the 2030 climate and energy framework, both in the emissions trading sector and in the non-traded sector" [42].

The Cuba NDC was also sent in 2015, and in addition to a succinct analysis of the country's circumstances facing the effects of the climate change, it has a list of actions that Cuba intends to take to mitigate these (previously clarifying that the compromises are on a voluntary basis and are not compulsory). Two categories are identified; adaptation and mitigation. The first one is focused on actions to diminish coastal vulnerability, recovering natural land and to establish monetarization systems for better decision making. The second one includes actions to contribute to the international effort to reduce climate change and are centered on the changing of lightbulbs towards a more sustainable model, the rehabilitation of electric networks and the efficient use of energy [43].

According to the Renewable Energies website, "the creation of renewable energy plants has increased in Spain over the last year (392 MWh more wind power in 2018) as well as investment in the sector, in order to comply with the agreement established by the EU ( ... ). Spain is today the fifth European photovoltaic market in installed power and the most desirable renewable market, especially for its photovoltaic growth potential. ( ... ). Spain should be able to lead the European photovoltaic market because the south of the Spain receives as much sunlight as North Africa, $2000 \mathrm{KWh}$ per square meter per year". However, at present, and according to the 2018 data of Red Eléctrica Española, within the clean generation mix, although wind power accounted for $49 \%$, and hydraulics $34 \%$, solar only grew $11 \%$. In other words, Spain does not use this energy as it should [44].

Following the objectives of the Paris Agreement, in Spain, more than 7.5 billion euros were invested in electricity generation in 2018, the sun and wind being the best allies to meet this goal. In addition, many houses in Spain are energy self-sufficient or energy efficient, something that in the future will be more generic.

On the other hand, Cuba will attempt in the coming years to install 19 bioelectric generation plants on the island. However, for the country to pay off such an investment, there are several challenges: meeting the deadlines for investments in the Ciro Redondo plant's bioelectric plant, increasing sugarcane production, and achieving energy forestry. Good progress in these commitments will depend on the fact that the bioelectric plants work effectively and that this experience becomes a benchmark for other similar envisaged efforts [45].

The "EU-Cuba Expert Exchange" project to promote renewable energy sources and energy efficiency in Cuba is financed by the European Union and managed by the International Foundation and for Iberoamerica of Public Administrations and Policies (FIIAPP). The main objective of the project is to support the efforts of the Cuban government aimed at the efficient and sustainable management of its resources with a view to diversifying Cuba's energy matrix. The project is part of the Cuban Energy Support Program developed as a cooperation strategy between the EU and Cuba, with 18 million euros of funding, distributed among four components and administered by various participants. It has been included in the "EU-Cuba Expert Exchange Programme" so that it can benefit from the existing operational structure and a successful methodology [46].

Concerning the relationship between Cuba, the European Union and Spain in the field of renewable energies, the Political Dialogue and Cooperation Agreement between the European Union and its Member States, on the one hand, and the Republic of Cuba, on the other, signed on 3 November 2016, dedicates its Article 54 to energy, including energy renewable, which figures among the fields of common interests for both parties [47] (p. 5). In addition, on November 2018, there was already talk of renewable energy source (RES) projects for 18 rural communities that will be developed in Cuba with the collaboration of the European Union, which will provide financing with a value of 20 million dollars.

The conclusion of those agreements reflects that the issue of sustainable development and the total substitution of electricity generation from non-renewable sources is global in resolution and requires supranational coordination (see the extensive Leal-Arcas' bibliography in this regard [48,49], among others). 
Cuba and the EU strengthened their cooperation on renewable energies in May 2018 when they signed a program in Brussels to support the Caribbean country to reach its goal of obtaining $24 \%$ of its electricity from renewable energy sources. Thus, the Cuban Government is committed to renewable energy with the objective that by 2030 , these sources provide the national system with 2334 megawatts from industrial biogas plants, bioelectric plants, photovoltaic solar panels, wind farms and small hydroelectric plants.

This project of renewable energy sources (solar photovoltaic, thermal, wind or biogas), signed in 2018, will be developed in Cuba with the collaboration of the European Union (EU) that will provide financing worth 20 million dollars. The starting point is the central province of Santo Espíritu, which will count USD 7 million and the participation of the Center for Studies of Energy and Industrial Processes of the José Martí University. The initial works are aimed at the towns of Alazanes, Yaguá, Manacal de Línea, Cuatro Veredas and Fomento in order to provide them with electricity $24 \mathrm{~h}$ a day, although the ultimate goal is to reach the towns that are outside the national electric power system and currently receive limited service through generator sets. The type of energy to be applied is still under study.

Cuba and Spain have also established lines of collaboration on climate change and its impacts. In fact, in December 2018, a project entitled "Strengthening of capacities and tools for assessing impacts and vulnerability in the north-western coastal zone of Cuba in the face of hurricanes and climate change" that studies the impacts of climate change on the north western coast of the island was presented. In addition to assessing the risks, the project has trained technicians of the Cuban administration and has created a database to monitor climate change impacts. The Spanish experience in adaptation to climate change has been key in the development of the initiative, which gives continuity to Spain's work in Latin America through the Iberoamerican Network of Climate Change Offices (RIOCC), the Economic Commission for Latin America and the Caribbean (ECLAC), and with the support of the Spanish Agency for International Cooperation for Development (AECID). "The area in which the project has been implemented is of extraordinary importance for the country, since it includes high-density population centers with high growth rates, as well as intense tourist, industrial and maritime-port activity. For this reason, the assessment of risks in the face of climate change and extreme events has taken into consideration the human, environmental and socio-economic dimensions to support decision-making and the determination of efficient adaptation policies and measures. In addition, thanks to this initiative, a high-resolution database has been created to monitor climate risks and hurricane impacts in the area and has enabled the technicians of the Cuban administration in charge of these issues to be trained" [50]. This project has had the participation of the Institute of Environmental Hydraulics of the University of Cantabria and that of the Cuban Government itself and has been funded through a contribution from Spain to the Economic Commission for Latin America and the Caribbean (ECLAC).

\section{Discussion}

Spain and Cuba currently depend on crude oil and its derivatives. However, with very favorable climatic conditions, these countries seem to be committed to making the necessary changes to achieve energy generation through renewable sources.

Nevertheless, the analysis of the legal framework carried out in this study shows that, from this point of view, their current positions seem diametrically opposed. Cuba is still taking the first steps to establish mechanisms that enhance the use of renewable energies and its current renewable electricity generation still only covers a very low part of the potential demand. By contrast, Spain has a solid legislative framework derived from European directives and supported by a Draft Climate Change Law and recent modifications to stop sanctioning self-consumption.

The surrounding environment related to the renewable energies in both countries can help to increase the impact of renewable energies in the energetic mix. In the case of Spain, European legislation has given decisive support for renewable energies, from which Spain has clearly benefited, and which 
seems assured as a result of the European Elections in May 2019, where parties that expressed stronger measures against climate change achieved substantial representation. For Cuba, the current situation in the South American continent can serve as an example of the future directions it could take in order to improve its situation.

In the development of further legislation for renewable energies in the Caribbean country, European and Spanish "green" positions can be very useful. This paper has analyzed the existing ties between the Caribbean country, Spain and the EU, which could be the basis for supporting a model in which Cuba has an outstanding natural resource endowment and where similarities with Spain can generate positive synergies based on the European experience.

The limitations of the study are set on the scarce availability of data from Cuba, which impedes a more accurate comparison of the energy production and its evolution. The further lines of research from the stated results will be to go deeper on the effect that the financing policies to foster renewable energies have in the real production.

Waiting for the disappearance of hydrocarbons to take these decisions seriously would economically harm both these countries. However, everything seems to indicate that, in addition to being aware of their favorable geo-meteorological conditions, Cuba and Spain's road map is very clear with both opting for the renewable pathway as the only form of energy generation.

\section{Conclusions}

Although it is true that the objective of this article has been to compare to what extent two countries, economically so different but so similar with respect to their atmospheric conditions, propose the generation of electricity from renewable sources, this is only the first step. Since the issue of substituting non-renewable sources for non-renewable sources is a global issue, the next step we consider is to discover the similarities and differences between the countries on a global scale, in this matter.

For following research, after compiling quantitative information referring to variables related to the generation of electricity with renewable and non-renewable sources by country (from the five continents, with emphasis on the most electricity-consuming countries), a multivariate analysis technique will be applied to help show the similarities between the countries on this issue. This is with the aim to evaluate whether or not there are similarities between some developed countries, with years of regulations and application for sustainability, and undeveloped ones, which have not joined international treaties regarding the protection of the environment and climate change.

This future line of research is supported by the fact that the environment and sustainable development are aspects that each country must protect, but assuming jointly developed regulations at the global level. Therefore, it is necessary to know the similarities and differences that exist among the most electricity-consuming countries so that the political considerations established at the global level are not foreign to the reality in which each country is currently situated. National efforts alone are worthless but much good can be extracted from learning experiences among countries. This article highlights the value of the common framework that the EU offers (among others) in renewable energies and how it could contribute to Cuba's faster development in the field.

The experience of Cuba, and its commitment to fight climate change, could also be valuable for the EU, and specially for the southern countries who face similar threats in terms of coastal erosion and agricultural land loss. In the current context of health and economic crises, the new green deals seem to be the proposed solution to solve the climate, the employment and social problems of the present. Increasing collaboration, even between countries with opposite political systems, can only do more good. 
Author Contributions: Conceptualization, Á.G.L., M.H.L., F.J.M.Á. and J.M.J.; methodology, Á.G.L., M.H.L., F.J.M.Á. and J.M.J.; validation, Á.G.L., M.H.L., F.J.M.Á. and J.M.J.; formal analysis, Á.G.L., M.H.L., F.J.M.Á. and J.M.J.; investigation, Á.G.L., M.H.L., F.J.M.Á. and J.M.J.; resources Á.G.L., M.H.L., F.J.M.Á. and J.M.J.; data curation, Á.G.L., M.H.L., F.J.M.Á. and J.M.J.; writing—original draft preparation, Á.G.L., M.H.L., F.J.M.Á. and J.M.J.; writing—review and editing, Á.G.L., M.H.L., F.J.M.Á. and J.M.J.; supervision, Á.G.L., M.H.L., F.J.M.Á. and J.M.J.; funding acquisition, Á.G.L., M.H.L., F.J.M.Á. and J.M.J. All authors have read and agreed to the published version of the manuscript.

Funding: This research was funded by Ayuda para potenciar la Actividad Investigadora en Ciencias Sociales y Juridicas, Artes y Humanidades dentro del Programa de Incentivación de la Actividad Investigadora de la Universidad de La Laguna. Grant number 2019/0001935.

Conflicts of Interest: The authors declare no conflict of interest.

\section{References}

1. International Renewable Energy Agency-IRENA. Statistical Data and Reports Extracted (Several Years); International Renewable Energy Agency: Abu Dhabi, UAE, 2017.

2. International Renewable Energy Agency-IRENA. Renewable Capacity Statistics 2020; International Renewable Energy Agency: Abu Dhabi, UAE, 2020. Available online: https://www.irena.org/publications/2020/Mar/ Renewable-Capacity-Statistics-2020 (accessed on 20 January 2020).

3. Owusu, P.A.; Asumadu-Sarkodie, S. A review of renewable energy sources, sustainability issues and climate change mitigation. Cogent Eng. 2016, 3, 1167990. [CrossRef]

4. Farrok, O.; Ahmed, K.; Tahlil, A.D.; Farah, M.M.; Kiran, M.R.; Islam, M. Electrical Power Generation from the Oceanic Wave for Sustainable Advancement in Renewable Energy Technologies. Sustainability 2020, 12, 2178. [CrossRef]

5. Kriegler, E.; Weyant, J.P.; Blanford, G.J.; Krey, V.; Clarke, L.; Edmonds, J.; Fawcett, A.; Luderer, G.; Riahi, K.; Richels, R.; et al. The role of technology for achieving climate policy objectives: Overview of the EMF 27 study on global technology and climate policy strategies. Clim. Chang. 2014, 123, 353-367. [CrossRef]

6. Edenhofer, O.; Pichs-Madruga, R.; Sokona, Y.; Seyboth, K.; Kadner, S.; Zwickel, T.; Eickemeier, P.; Hansen, G.; Schlömer, S.; von Stechow, C. Renewable Energy Sources and Climate Change Mitigation: Special Report of the Intergovernmental Panel on Climate Change; Cambridge University Press: Cambridge, UK, 2011; ISBN 1-139-50559-9.

7. Al Irsyad, M.I.; Halog, A.; Nepal, R. Renewable energy projections for climate change mitigation: An analysis of uncertainty and errors. Renew. Energy 2019, 130, 536-546. [CrossRef]

8. Ireland, P.; Clausen, D. Local action that changes the world: Fresh perspectives on climate change mitigation and adaptation from Australia. In Managing Global Warming; Elsevier: Amsterdam, The Netherlands, 2019; pp. 769-782.

9. Deloitte; UNEF. La Energía Solar Fotovoltaica en España. Desarrollo Actual y Potencial; Unión Española Fotovoltaica: Madrid, Spain, 2017; p. 42.

10. Delacámara, G.; Oyarzún, D.A. Análisis Económico de los Costos Externos Ambientales de la Generación de Energía Eléctrica; CEPAL: Santiago de, Chile, 2007; p. 110.

11. Qin, T. Challenges for sustainable development and its legal response in China: A perspective for social transformation. Sustainability 2014, 6, 5075-5106. [CrossRef]

12. Aseeva, A. (Un) Sustainable Development (s) in International Economic Law: A Quest for Sustainability. Sustainability 2018, 10, 4022. [CrossRef]

13. Mélon, L. More Than a Nudge? Arguments and Tools for Mandating Green Public Procurement in the EU. Sustainability 2020, 12, 988. [CrossRef]

14. Laino, L.D. Un Análisis de la Política Energética en Cuba. Poblac. Desarro. 2008, 35, 45-62.

15. Ministerio de Ciencia, Tecnología y Medio Ambiente de la República de Cuba. Política Para el Desarrollo Perspectivo de las Fuentes Renovables y el uso Eficiente de la Energía; Decreto Presidencial No. 3 del 11 de diciembre de 2012; Ministerio de Ciencia, Tecnología y Medio Ambiente de la República de Cuba: Havana, Cuba, 2012.

16. Instituto de Comercio Exterior. Información de Mercados. Noticias; Ministerio de Industria, Comercio y Turismo: Madrid, España, 2019.

17. Ministerio para la Transición Ecológica y el Reto Demográfico. Marco Estratégico de Energía y Clima; Ministerio para la Transición Ecológica y el Reto Demográfico: Madrid, España, 2019. 
18. Ministerio para la Transición Ecológica y el Reto Demográfico. Anteproyecto de Ley de Cambio Climático y Transición Energética (APLCCTE); Ministerio para la Transición Ecológica y el Reto Demográfico: Madrid, Gobierno de España, 2020.

19. Jacobs, D. Renewable Energy Policy Convergence in the EU: The Evolution of Feed-In Tariffs in Germany, Spain and France; Routledge: London, UK, 2016; ISBN 1-317-06631-6.

20. Heras-Saizarbitoria, I.; Sáez, L.; Allur, E.; Morandeira, J. The emergence of renewable energy cooperatives in Spain: A review. Renew. Sustain. Energy Rev. 2018, 94, 1036-1043. [CrossRef]

21. Ciarreta, A.; Espinosa, M.P.; Pizarro-Irizar, C. Has renewable energy induced competitive behavior in the Spanish electricity market? Energy Policy 2017, 104, 171-182. [CrossRef]

22. Sorman, A.H.; Pizarro-Irizar, C.; García-Muros, X.; González-Eguino, M.; Arto, I. On a rollercoaster of regulatory change-risks and uncertainties associated with renewable energy transitions. In Narratives of Low-Carbon Transitions, 1st ed.; Hanger-Kopp, S., Lieu, J., Nikas, A., Eds.; Routeledge: London, UK; New York, NY, USA; pp. 121-138. 2019.

23. Bressers, H.; de Boer, C. Losing the roadmap: Renewable energy paralysis in Spain and its implications for the EU low carbon economy. Renew. Energy 2016, 89, 680-694.

24. Del Río, P.; Janeiro, L. Overcapacity as a barrier to renewable energy deployment: The Spanish case. J. Energy 2016, 2016, 1-10. [CrossRef]

25. Bailera, M.; Lisbona, P. Energy storage in Spain: Forecasting electricity excess and assessment of power-to-gas potential up to 2050. Energy 2018, 143, 900-910. [CrossRef]

26. Girard, A.; Gago, E.; Ordoñez, J.; Muneer, T. Spain's energy outlook: A review of PV potential and energy export. Renew. Energy 2016, 86, 703-715. [CrossRef]

27. Lewis, J.I. The evolving role of carbon finance in promoting renewable energy development in China. Energy Policy 2010, 38, 2875-2886. [CrossRef]

28. Abolhosseini, S.; Heshmati, A. The main support mechanisms to finance renewable energy development. Renew. Sustain. Energy Rev. 2014, 40, 876-885. [CrossRef]

29. Boletín Oficial del Estado. Real Decreto 2818/1998, de 23 de Diciembre, Sobre Producción de Energía Eléctrica por Instalaciones Abastecidas por Recursos o Fuentes de Energía Renovables, Residuos y Cogeneración; Ministerio de Industria y Energía: Madrid, Gobierno de España, 2016.

30. Boletín Oficial del Estado. Real Decreto-ley 1/2012, de 27 de enero, por el que se Procede a la Suspensión de los Procedimientos de Preasignación de Retribución y a la Supresión de los Incentivos Económicos para Nuevas Instalaciones de Producción de Energía Eléctrica a Partir de Cogeneración, Fuentes de Energía Renovables y Residuos. Jefatura de Estado; Boletín Oficial del Estado: Madrid, Gobierno de España, 2012.

31. Boletín Oficial del Estado. Real Decreto 900/2015, de 9 de Octubre, por el que se Regulan las Condiciones Administrativas, Técnicas y Económicas de las Modalidades de Suministro de Energía Eléctrica con Autoconsumo y de Producción con Autoconsumo; Ministerio de Industria, Energía y Turismo: Madrid, Gobierno de España, 2015.

32. Boletín Oficial del Estado. Real Decreto 244/2019, de 5 de abril, por el que se Regulan las Condiciones Administrativas, Técnicas y Económicas del Autoconsumo de Energía Eléctrica. Ministerio para la Transición Ecológica y el Reto Demográfico; Boletín Oficial del Estado: Madrid, Gobierno de España, 2019.

33. International Energy Agency-IEA. Data and Statistics (Several Years) 2005-2017; International Energy Agency-IEA: Paris, France. Available online: https://www.iea.org/statistics (accessed on 6 April 2020).

34. Bravo Hidalgo, D. Energía y desarrollo sostenible en Cuba. Cent. Azúcar 2015, 42, 14-25.

35. Avila-Prats, D.; Alesanco-García, R.; García-García, F. Coste del kWh eólico generado en Cuba, a partir de datos de viento de una región de buenos potenciales eólicos. Ing. Mec. 2010, 13, 38-45.

36. Moreno-Figueredo, C. Cuba hacia 100\% con energías renovables. Rev. Energía Tú 2013, 62.

37. Club Español de la Energía. Estrategia energética española a medio y largo plazo: Mix y mercados. Cuad. Energía 2015, 72-86.

38. AEE. La Eólica en España; Asociación Empresarial Eólica: Madrid, España, 2019.

39. UNEF. La Energía Fotovoltaica. Una Alternativa Real; Informe Anual 2015; Unión Española Fotovoltaica: Madrid, Spain, 2015.

40. European Commision. Report of the European Commission to the Parliament and the Council; Renewable Energy Progress Report; European Commission: Brussels, Belgium, 2017; p. 18. 
41. Boletín Oficial de Canarias. Resolución de 4 de Agosto de 2008, por la que se hace Público el Acuerdo de la Comisión de Ordenación del Territorio y Medio Ambiente de Canarias, en sesión celebrada el 27 de junio de 2008, relativo a la aprobación de la Declaración de Impacto Ambiental del Proyecto Denominado Concesión del Aprovechamiento Hidroeólico de El Hierro, Promovido por Gorona del Viento El Hierro, S.A., en el Término Municipal de Valverde (El Hierro)-Expte. 2008/0478. Dirección General de Calidad Ambiental; Gobierno de Canarias. España: Santa Cruz de Tenerife, Gobierno de Canarias, 2008.

42. Latvian Presidency of the Council of the EU. Intended Nationally Determined Contribution of the EU and Its Member States; Latvian Presidency of the Council of the EU: Riga, Latvia, 2015; p. 5.

43. República de Cuba. Contribución Nacionalmente Determinada, Convención Marco de las Naciones Unidas Sobre el Cambio Climático; República de Cuba: La Habana, Cuba, 2015; p. 20.

44. Red Eléctrica Española. Datos Estadísticos 2018; Red Eléctrica de España: Madrid, España, 2018.

45. Sánchez Abreu, J.E. La industria azucarera importante fuente para la generación de electricidad en Cuba. Caribeña Cienc. Soc. 2018.

46. FIIAPP. Cuba-Renewables Project. Fundación Internacional y para Iberoamérica de Administración y Políticas Públicas; FIIAPP: Madrid, Gobierno de España, 2018.

47. Bacaria, J.; Serrano, E. La Transformación de la Economía Cubana, Frente al Acuerdo de Diálogo Político y Cooperación Entre la Unión Europea y Cuba, Foro Europa-Cuba; Jean Monnet Network: Barcelona, Catalonia, Spain, 2020; pp. 1-15.

48. Leal-Arcas, R. Solutions for Sustainability: How the International Trade, Energy and Climate Change Regimes Can Help; Springer Nature: Berlin, Germany, 2019; ISBN 3-030-23933-0.

49. Leal-Arcas, R. The European Energy Union. The Quest for Secure, Affordable and Sustainable Energy. European Energy Strategy Studies; CLAYES\&CASTELS: Deventer, The Netherlands, 2016.

50. Ministerio para la Transición Ecológica y el Reto Demográfico. Encuentro bilateral Cuba-España en la COP24; Ministerio para la Transición Ecológica y el Reto Demográfico: Madrid, Gobierno de España, 2018.

(C) 2020 by the authors. Licensee MDPI, Basel, Switzerland. This article is an open access article distributed under the terms and conditions of the Creative Commons Attribution (CC BY) license (http://creativecommons.org/licenses/by/4.0/). 